Research Article

\title{
New Bioactive Metabolites from the Thermophilic Fungus Penicillium sp. Isolated from Ghamiqa Hot Spring in Saudi Arabia
}

\author{
Raha Orfali 1 and Shagufta Perveen \\ Department of Pharmacognosy, College of Pharmacy, King Saud University, P.O. Box 2457, Riyadh 11451, Saudi Arabia \\ Correspondence should be addressed to Raha Orfali; rorfali@ksu.edu.sa and Shagufta Perveen; shagufta792000@yahoo.com
}

Received 14 March 2019; Revised 12 June 2019; Accepted 24 June 2019; Published 6 August 2019

Academic Editor: Artur M. S. Silva

Copyright (C) 2019 Raha Orfali and Shagufta Perveen. This is an open access article distributed under the Creative Commons Attribution License, which permits unrestricted use, distribution, and reproduction in any medium, provided the original work is properly cited.

\begin{abstract}
The thermophilic fungus Penicillium species was isolated from Ghamiqa hot spring sediments in Saudi Arabia. Extract of Penicillium species cultured on solid rice medium yielded two new compounds 3-(furan 12-carboxylic acid)-6-(methoxycarbonyl)-4-hydroxy-4-methyl-4 and 5-dihydro-2H-pyran $13 \alpha$-methyl-7-hydroxy-5-carboxylic acid methyl ester-1-indanone 2. In addition, three known compounds, austinol 3, emodin 4, and 2-methyl-penicinoline 5, were isolated. The structures of the new compounds were unambiguously determined by comprehensive analysis of spectroscopic data, one- and two-dimensional NMR spectroscopy, and high-resolution mass spectrometry. All isolated metabolites were studied for their antibiotic effect against several pathogenic bacteria and for their cytotoxicity against the lymphoma human cancer cell line HTB-176. Austinol 3 exhibited strong antibacterial activity against $P$. aeruginosa bacterial strain with an MIC value of $0.13 \pm 0.4 \mu \mathrm{g} \cdot \mathrm{mL}^{-1}$, whereas emodin 4 demonstrated significant cytotoxicity against the tested HTB-176 cell line with an $\mathrm{IC}_{50}$ value of $2 \pm 7.6 \mu \mathrm{M}$, while the other compounds were moderate to inactive with $\mathrm{IC}_{50}$ ranging from $4.3 \pm 0.25-22 \pm 2.94 \mu \mathrm{M}$ in this assay.
\end{abstract}

\section{Introduction}

Thermophilic fungi are untapped source for novel thermostable enzymes which are essential for biotechnological and industrial applications [1]. These fungi can thrive at temperature more than $50^{\circ} \mathrm{C}$ as a maximum and above $20^{\circ} \mathrm{C}$ as a minimum using homeoviscous adaptation technique [2-5]. This unique adaption mechanism allows thermophilic fungi to survive in extreme heated regions, such as deep sea hydrothermal vents, hot springs, and volcanic environments, and facilitates their probability to produce novel and bioactive secondary metabolites [2]. The attention to investigate bioactive components from thermophilic fungi has been recently initiated by limited research groups. Their results showed diversity of secondary metabolites, including polyketides, alkaloids, and peptides, with remarkable cytotoxic and antimicrobial activities [6-10].

The ascomycetous genus Penicillium is one of the most abundant strains in the kingdom fungi. It comprises more than 300 accepted species. It is ubiquity exists in most habitats: terrestrial, marine, and extremophilic regions [11]. Penicillium is known to accumulate numerous new bioactive secondary metabolites since the discovery of penicillin $\mathrm{G}$ from $P$. notatum [12]. Up to date, plenty of bioactive compounds have been reported from Penicillium isolates and still new biologically active secondary metabolites continue to be discovered from this genus indicating its importance as a reservoir for novel bioactive components with great significance to pharmaceutical industries [13].

Under the ongoing search for new bioactive metabolites from extremophilic fungi [14-16], investigations have been conducted on the thermophilic fungus, Penicillium sp., isolated from the sediment of Ghamiqa hot springs located $180 \mathrm{~km}$ south of Makkah al-Mukarramah, Saudi Arabia. The temperature of the hot springs reaches from 45 to $65^{\circ} \mathrm{C}$. The literature review on secondary metabolites of thermophilic fungi from hot springs regions indicated that isolation, identification, and structural elucidation of bioactive components from thermophilic fungi inhabited in hot springs especially Saudi regions has not been studied extensively. An ethyl acetate (EtOAc) extract of Penicillium sp. cultured on solid rice medium showed significant antimicrobial and 
moderate cytotoxic activities against selected cell lines. Bioassay-guided fractionation of the extract afforded two new compounds (1-2) together with the previously reported austinol (3) [17], emodin (4) [18], and 2-methyl-penicinoline (5) [19]. Details on the isolation and structure elucidation of compounds 1-5, their biological activities, and statistical analysis are listed herein.

\section{Materials and Methods}

2.1. General Experimental Procedures. Optical rotations were measured on a JASCO P-2000 Series polarimeter (JASCO Corporation, 2967-5, Tokyo, Japan). The ${ }^{1} \mathrm{H}$ (500 MHz), ${ }^{13} \mathrm{C}$ NMR (125 MHz), and 2D NMR spectra were recorded at $25^{\circ} \mathrm{C}$ on a Bruker AMX-700 spectrometer with tetramethylsilane (TMS) as an internal standard. Chemical shifts are in ppm $(\delta)$, referring to the deuterium solvent peaks at 2.50 (DMSO- $\mathrm{d}_{6}$ ) and 39.5 for ${ }^{1} \mathrm{H}$ and ${ }^{13} \mathrm{C}$, respectively. Mass spectra ESI-MS analyses were measured on an Agilent Triple Quadrupole 6410 QQQ LC/MS mass spectrometer with an ESI ion source (gas temperature is $350^{\circ} \mathrm{C}$, nebulizer pressure is $60 \mathrm{psi}$ and gas flow rate is $12 \mathrm{~L} / \mathrm{min}$ ), operating in the negative and positive scan modes of ionization through the direct infusion method using $\mathrm{CH}_{3} \mathrm{OH} \backslash \mathrm{H}_{2} \mathrm{O}(1: 1 \mathrm{v} / \mathrm{v})$ at a flow rate of $0.2 \mathrm{~mL} / \mathrm{min}$. Positive and negative ion HR-ESIMS spectra were recorded using a LTQ Orbitrap XL mass spectrometer (Thermo Fisher Scientific, Waltham, MA). Solvents were distilled before use, and spectral-grade solvents were used for spectroscopic analysis. HPLC analysis was performed on Prominence Shimadzu LC Solution (Kyoto, Japan), and the system was equipped with a CBM$20 \mathrm{~A}$ communication bus module, two LC-10AD pumps, a CTO-10AC column oven, and an SPD-10AV diode array detector. A Shim-pack VP-ODS $(150 \mathrm{~mm} \times 4.6 \mathrm{~mm}, 5.0 \mu \mathrm{m}$, Shimadzu) analytical column was used and kept at $40^{\circ} \mathrm{C}$. The mobile phase consisted of water containing $0.1 \%$ trifluoroacetic acid (A) and $\mathrm{CH}_{3} \mathrm{OH}(\mathrm{B})$. The flow rate was set at $0.5 \mathrm{~mL} / \mathrm{min}$, and the injection volume was $25 \mu \mathrm{L}$. The DAD detection was achieved in the range of $254 \mathrm{~nm}$. HPLC separation was performed on a semipreparative HPLC system of Shimadzu LC Solution, Kyoto, Japan (pump L7100, UV detector L7400, column Europhere $100 \mathrm{C}_{18}$, $300 \times 8 \mathrm{~mm}$, Shimadzu) with a flow rate of $5.0 \mathrm{~mL} / \mathrm{min}$. Column chromatography included silica gel $60 \mathrm{M}(0.04-$ $0.063 \mathrm{~mm}$, Merck KGaA) and Sephadex LH-20 (E. Merck, Darmstadt, Germany). For thin layer chromatography (TLC) analysis, precoated silica gel $60 \mathrm{~F}_{254}$ TLC plates (aluminium sheets, Merck, Germany) were used followed by detection under UV $254 \mathrm{~nm}$ and $366 \mathrm{~nm}$ or by spraying with anisaldehyde reagent.

2.2. Fungal Material. The fungus RO-11 used in this study was isolated from the sediment Ghamiqa hot spring (45$65^{\circ} \mathrm{C}$ ) located $180 \mathrm{~km}$ south of Makkah Al-Mukarramah, Saudi Arabia, which was collected in September 2017. The isolation of the fungi has been done according to dilution platting technique as listed previously [20]. After serial dilution, the fungi were cultured on yeast starch agar plates and incubated at optimum temperature $50^{\circ} \mathrm{C}$ for 10 days.
2.3. Fungal Identification. The fungal strain was identified as Penicillium sp. according to a molecular biological protocol by DNA amplification and sequencing of the internal transcribed spacer (ITS) region as described previously [21]. After alignment into GenBank database, the similarities of the target sequences with the most related fungal strain RO11 yielded the accession number MK028998. A specimen of the strain has been kept in the collection of the author's laboratory (R. O.).

2.4. Fermentation. The fungal stain was cultivated on solid rice medium, which was prepared by autoclaving $\left(121^{\circ} \mathrm{C}\right.$, $20 \mathrm{~min}$ ) twenty $1 \mathrm{~L}$ Erlenmeyer flasks each containing $100 \mathrm{~g}$ of rice and $100 \mathrm{~mL}$ of water. The fungus, which almost covered the whole surface of yeast agar at $50 \pm 2^{\circ} \mathrm{C}$, was suspended onto the sterile rice medium under a clean bench. In an attempt to optimize the fermentation conditions, the flasks were statically incubated at $50^{\circ} \mathrm{C}$ for 10 days.

2.5. Extraction and Isolation. After fermentation, the whole rice broth was extracted repeatedly with equivalent amount of ethyl acetate (EtOAc) affording $(4.0 \mathrm{~g})$ brown residue. The resulting extract was then subjected to liquid-liquid partitioning between $n$-hexane and $90 \% \mathrm{MeOH}$ fraction. Several subfractions were obtained by fractionation of the methanolic extract using vacuum liquid chromatography (VLC) on silica gel 60 and eluted with a gradient of n-hexane to EtOAc and of dichloromethane to MeoH. Further purification was achieved by using Sephadex LH-20 as stationary phase and methanol $(50: 50 \mathrm{v} / \mathrm{v})$ as mobile phase. Similar fractions were combined with each other according to TLC readings and further purified by semipreparative HPLC using gradient system $\mathrm{MeOH}-\mathrm{H}_{2} \mathrm{O}$ from $40: 60$ to $70: 30$ in $30 \mathrm{~min}$ to afford the five compounds 1 ( $4.3 \mathrm{mg}), 2$ (3.6 mg), 3 (2.7 mg), 4 (5.2 mg), and 5 (12.8 mg).

Compound 1. White amorphous powder, $[\alpha]_{\mathrm{D}}^{25}-5.0$ (c $0.15, \mathrm{MeOH}) ;{ }^{1} \mathrm{H}$ and ${ }^{13} \mathrm{C} \mathrm{NMR}(500,125 \mathrm{MHz}$, in $\mathrm{CD}_{3} \mathrm{OD}$ ) (see Table 1); HR-ESI-MS: $m / z 305.3456$ $[\mathrm{M}+\mathrm{Na}]^{+}$(calcd for $\left.\mathrm{C}_{13} \mathrm{H}_{14} \mathrm{O}_{7} \mathrm{Na} 305.3467\right)$.

Compound 2. White amorphous powder, $[\alpha]_{\mathrm{D}}{ }^{25}-25$ (c $0.15, \mathrm{MeOH}) ;{ }^{1} \mathrm{H}$ and ${ }^{13} \mathrm{C} \mathrm{NMR}(500,125 \mathrm{MHz}$, in DMSO) (see Table 2); HR-ESI-MS: $m / z 219.0656$ [M$\mathrm{H}]^{+}$, (calcd. 219.1920 for $\mathrm{C}_{12} \mathrm{H}_{11} \mathrm{O}_{4}$ ).

2.6. Antibacterial Assay. All five compounds were tested for their antibacterial activities against different Gram-positive and Gram-negative strains. The Gram-positive strains, Staphylococcus aureus (CP011526.1) and Bacillus licheniformis (KX785171.1), and the Gram-negative strains, Enterobacter xiangfangensis (CP017183.1), Escherichia fergusonii (CU928158.2), and Pseudomonas aeruginosa (NR117678.1), were inoculated in a nutrient broth for $24 \mathrm{~h}$ then spread on Muller Hinton agar plates. Wells were loaded with $10 \mu \mathrm{L}$ of the tested samples, and the growth of bacteria was noticed using amikacin as positive control. The clear area which had no bacterial growth was measured three times to 
TABle 1: ${ }^{1} \mathrm{H},{ }^{13} \mathrm{C}$ NMR, and HMBC spectroscopic data of compound $1\left(\mathrm{CD}_{3} \mathrm{OD}\right)$.

\begin{tabular}{lccc}
\hline & \multicolumn{3}{c}{1} \\
No. \# & $\delta_{\mathrm{H}}$ & $\delta_{\mathrm{C}}$ & HMBC \\
\hline 2 & $7.04(\mathrm{~s})$ & 141.9 & $\mathrm{C}-9, \mathrm{C}-3, \mathrm{C}-4, \mathrm{C}-6$ \\
3 & - & 109.9 & - \\
4 & - & 76.8 & - \\
5 & $2.39(\mathrm{~d}, J=13.5)$ & 36.6 & $\mathrm{C}-4, \mathrm{C}-6, \mathrm{C}-7, \mathrm{C}-8$ \\
& $2.52(\mathrm{dd}, J=2.5,13.5)$ & - & $\mathrm{C}-3, \mathrm{C}-4, \mathrm{C}-6, \mathrm{C}-7, \mathrm{C}-8$ \\
6 & $4.84^{*}$ & 72.6 & $\mathrm{C}-2, \mathrm{C}-4, \mathrm{C}-7$ \\
7 & - & 169.4 & - \\
8 & $1.65(\mathrm{~s})$ & 25.3 & $\mathrm{C}-3, \mathrm{C}-4, \mathrm{C}-5$ \\
9 & - & 137.4 & - \\
10 & $6.34(\mathrm{~d}, J=2.1)$ & 101.1 & $\mathrm{C}-3, \mathrm{C}-12$ \\
11 & $6.21(\mathrm{~d}, J=2.1)$ & 101.0 & $\mathrm{C}-9, \mathrm{C}-12, \mathrm{C}-13$ \\
12 & - & 165.2 & - \\
13 & - & 168.6 & - \\
$\mathrm{OCH}_{3}$ & $3.84(\mathrm{~s})$ & 51.8 & - \\
\hline
\end{tabular}

*Splitting cannot be calculated due to overlapping with solvent signal.

TABle 2: ${ }^{1} \mathrm{H},{ }^{13} \mathrm{C}$ NMR, and HMBC spectroscopic data of compound 2 (DMSO).

\begin{tabular}{lccc}
\hline & & 2 & \\
No. \# & $\delta_{\mathrm{H}}$ & $\delta_{\mathrm{C}}$ & HMBC \\
\hline 1 & - & 196.2 & - \\
2 & $2.22(\mathrm{~d}, J=19.0)$ & 42.8 & $\mathrm{C}-1, \mathrm{C}-3, \mathrm{C}-4 \mathrm{a}, \mathrm{C}-7 \mathrm{a}, \mathrm{C}-8$ \\
& $2.93(\mathrm{dd}, J=19.0$, & & C-1, C-3, C-4a, C-8 \\
& $6.5)$ & & C-1, C-2, C-4, C-4a, C-7a, C- \\
3 & $3.52(\mathrm{dd}, J=6.5,7.0)$ & 28.3 & 8 \\
4 & $6.91(\mathrm{~d}, J=2.0)$ & 103.3 & $\mathrm{C}-3, \mathrm{C}-5, \mathrm{C}-6, \mathrm{C}-7 \mathrm{a}, \mathrm{C}-9$ \\
5 & - & 135.2 & - \\
6 & $6.83(\mathrm{~d}, J=2.0)$ & 104.0 & $\mathrm{C}-4, \mathrm{C}-5, \mathrm{C}-9$ \\
7 & - & 164.2 & - \\
$7 \mathrm{a}$ & - & 148.0 & - \\
$4 \mathrm{a}$ & - & 145.1 & - \\
8 & $1.35(\mathrm{~d}, J=7.0)$ & 21.0 & $\mathrm{C}-2, \mathrm{C}-3, \mathrm{C}-4 \mathrm{a}$ \\
9 & - & 166.9 & - \\
$\mathrm{OCH}_{3}$ & $3.95(\mathrm{~s})$ & 56.8 & C-9 \\
$7-\mathrm{OH}$ & $11.1(\mathrm{~s})$ & - & - \\
\hline
\end{tabular}

calculate the zone of inhibition diameter and each time the mean was recorded. The minimal inhibitory concentration (MIC, $\mu \mathrm{g} \cdot \mathrm{mL}^{-1}$ ) was determined in this study by measuring the lowest concentration of the tested isolated compounds that will inhibit the bacterial growth according to the previously listed method [22].

2.7. Cytotoxicity Assay. Cytotoxicity of all isolated compounds were measured against HTB-176 human lymphoma cell line and assayed by the microculture tetrazolium (MTT) assay and compared with the untreated controls, according to the method as described before [23]. The 0.1\% EGMMEDMSO medium was used as negative control. The inhibition of cell growth was calculated in terms of $\mathrm{IC}_{50}$ value using Kahalalide $\mathrm{F}$ as positive control.
2.8. Statistical Analysis. Data analysis was expressed as mean \pm standard deviation (SD) of three replicates. Where applicable, the data were subjected to one-way analysis of variance (ANOVA). Based on Microsoft Excel 2010 and Origin 2019 statistical package analyses, the significant differences were considered statistically significant $P$ values $<0.05$.

\section{Results and Discussion}

The ethyl acetate extract of the thermophilic fungus Penicillium sp. RO-11 was obtained from the hot spring sediment after cultivation on yeast-starch agar medium under different temperatures $\left(15-65^{\circ} \mathrm{C}\right)$. The radial growth of the fungus on the plate was measured for 10 days. The optimum growth of Penicillium sp. RO-11 was detected in the range of $45-65^{\circ} \mathrm{C}$. Accordingly, the fungus was cultured on largescale solid rice medium at $50^{\circ} \mathrm{C}$. The fungal extract was partitioned between $n$-hexane and $90 \%$ aqueous methanol. The resulting methanol phase was fractionated and separated using a series of different chromatographic techniques to yield two new compounds $\mathbf{1}$ and $\mathbf{2}$ along with three known compounds including austinol 3, emodin 4, and 2-methylpenicinoline 5 (Figure 1).

Compound $\mathbf{1}$ was obtained as a yellow amorphous powder. The HRESIMS exhibited a prominent peak at $\mathrm{m} / \mathrm{z}$ $305.3456[\mathrm{M}+\mathrm{Na}]^{+}$, consistent with the molecular formula $\mathrm{C}_{13} \mathrm{H}_{14} \mathrm{O}_{7}$. It showed UV absorption maxima at $\lambda_{\max } 215$, 225,235 , and $275 \mathrm{~nm}$. The IR spectrum showed the absorption band at 3300-3260 (OH), 2850-2930 (aromatic system), and 1705-1735 (ester and acid carbonyls) $\mathrm{cm}^{-1}$. The carbon NMR spectral data of compound 1 showed thirteen carbon signals that were assigned to one methyl $\left(\delta_{\mathrm{C}} 25.3\right)$, one methylene $\left(\delta_{\mathrm{C}} 36.6\right)$, one methoxy $\left(\delta_{\mathrm{C}} 51.8\right)$, three olefinic methines $\left(\delta_{\mathrm{C}} 101.0,101.1\right.$ and 141.9), one oxygenated methine $\left(\delta_{\mathrm{C}} 72.6\right)$, one carbinol carbon $\left(\delta_{\mathrm{C}} 76.8\right)$, four oxygenated $s p^{2}$ carbons $\left(\delta_{\mathrm{C}} 137.4,165.2,168.6\right.$, and 169.4), and one quaternary $s p^{2}$ carbon (109.9). Its proton NMR spectrum displayed the signals of two doublets for the 2, 5di-substituted heterocyclic ring at $\delta_{\mathrm{H}} 6.21$ and 6.34 (each d, $J=2.1 \mathrm{~Hz}$ ) and a singlet of an olefinic proton at $\delta_{\mathrm{H}} 7.04$. It further showed the signal of one methylene proton at $2.39(\mathrm{~d}$, $J=13.5 \mathrm{~Hz})$ and $2.52(\mathrm{dd}, J=2.5,13.5 \mathrm{~Hz})$ and one methine proton signal at $\delta_{\mathrm{H}} 4.84$ (overlapped with NMR solvent signal). Both of these $\mathrm{CH}_{2}$ and $\mathrm{CH}$ protons showed strong ${ }^{1} \mathrm{H}-{ }^{1} \mathrm{HCOSY}$ correlations which confirm its adjacent positions. Two carbonyl carbons that appeared at $\delta_{\mathrm{C}} 168.6$ and $\delta_{\mathrm{C}} 169.4$ were in good agreement with values reported for either carboxylic acid or ester moieties. Based on proton and carbon spectral results, it could be said that compound $\mathbf{1}$ consists of furan and dihydropyran ring skeleton along with two carbonyl moieties [24]. The proton at $\delta_{\mathrm{H}} 7.04$ showed strong ${ }^{3} J$ HMBC correlations with C-9 $\left(\delta_{\mathrm{C}} 137.4\right), \mathrm{CH}-6\left(\delta_{\mathrm{C}}\right.$ $72.6)$, and $C-4\left(\delta_{\mathrm{C}} 76.8\right)$ and ${ }^{2} J$ correlations with $\mathrm{C}-3\left(\delta_{\mathrm{C}}\right.$ 109.9). It further showed weak ${ }^{4} J$ correlations with $\mathrm{CH}_{2}-5$ $\left(\delta_{\mathrm{C}} 36.6\right)$. The methylene protons $\delta_{\mathrm{H}} 2.39,2.52$ showed ${ }^{3} \mathrm{~J}$ HMBC correlations with $\mathrm{CH}_{3}-8$ (25.3), C-3 $\left(\delta_{\mathrm{C}} 109.9\right)$, and C-7 $\left(\delta_{\mathrm{C}} 169.4\right)$ and ${ }^{2} J$ correlations with $\mathrm{CH}-6\left(\delta_{\mathrm{C}} 72.6\right)$ and C-4 $\left(\delta_{\mathrm{C}} 76.8\right)$. H-10 proton at $\delta_{\mathrm{H}} 6.34$ of the furan ring 


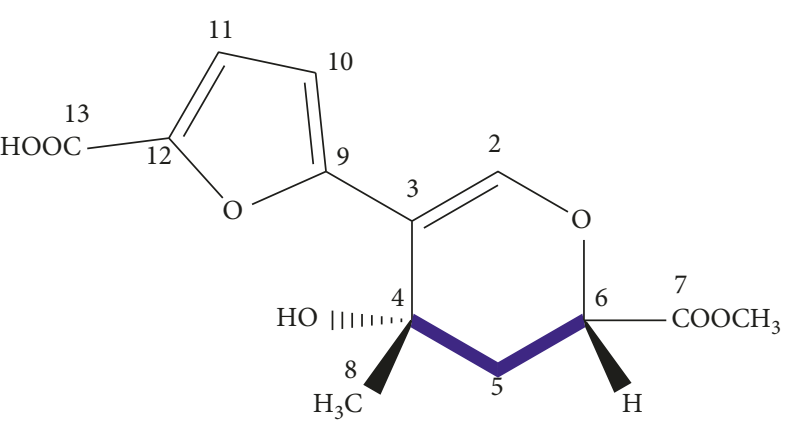

1

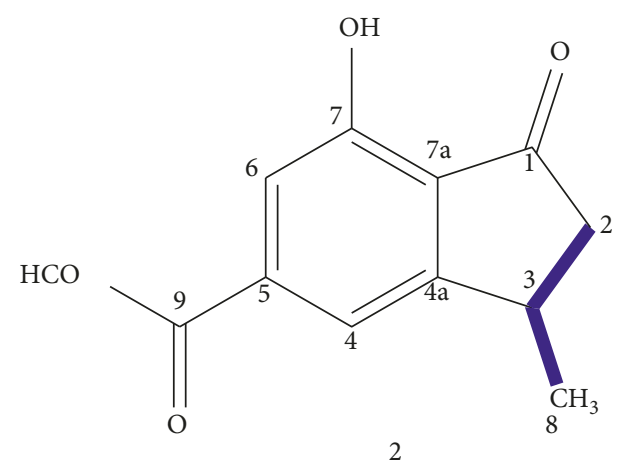<smiles></smiles><smiles>Cc1cc(O)c2c(c1)C(=O)c1cc(O)cc(O)c1C2=O</smiles><smiles>COC(=O)C1C(=O)c2ccccc2NC1c1ccc[nH]1</smiles>

Figure 1: Structures of compounds $\mathbf{1 - 5}$ and key ${ }^{1} \mathrm{H}-{ }^{1} \mathrm{H}$ COSY ( $)$ correlations of $\mathbf{1}$ and $\mathbf{2}$.

showed strong $\mathrm{HMBC}^{3} J$ correlations with the C-3 $\left(\delta_{\mathrm{C}} 109.9\right)$ carbon of the dihydropyran ring. These correlation data established the C-3/C-9 connectivity between the furan and dihydropyran ring. The HMBC cross peaks from oxymethine proton $\left(\delta_{\mathrm{H}} 4.84\right)$ and methylene protons $\left(\delta_{\mathrm{H}} 2.39\right.$, $2.52)$ to carbonyl carbon at $\delta_{\mathrm{C}} 169.4$ suggested the presence of ester moiety at C-6 position; while methoxy protons $\left(\delta_{\mathrm{H}}\right.$ 3.84) showed strong ${ }^{3} J$ HMBC correlations with C-7. Furthermore, the strong $\mathrm{HMBC}$ cross peaks from $\mathrm{CH}_{3}$ protons $\left(\delta_{\mathrm{H}} 1.65\right)$ to $\mathrm{C}-3\left(\delta_{\mathrm{C}} 109.9\right), \mathrm{C}-4\left(\delta_{\mathrm{C}} 76.8\right)$, and C-5 $\left(\delta_{\mathrm{C}} 36.6\right)$ confirmed the position of methyl group at C-4 position. The downfield chemical shifts of methyl group $\left(\delta_{\mathrm{H}} 1.65, \delta_{\mathrm{C}} 25.3\right)$ suggested the presence of hydroxyl moiety at the same position $\mathrm{C}-4$. The furan ring protons $\left(\delta_{\mathrm{H}} 6.21,6.34\right)$ showed long-range $\mathrm{HMBC}$ correlations with $\mathrm{C}-3, \mathrm{C}-9, \mathrm{C}-12$, and
C-13 which confirmed the carbon's connectivity from C-3 to C-13. The observed ROESY correlations of protons $\mathrm{H}-6$, $\mathrm{H}-5$, and $\mathrm{H}_{3}-8$ indicated that these protons are cofacial $[25,26]$. The absolute configuration of $\mathbf{1}$ was not determined since the quantity of the compound was not sufficient to obtain Mosher esters. Taken all together, the structure of compound 1 was established as 3-(furan 12-carboxylic acid)6-(methoxycarbonyl)-4-hydroxy-4-methyl-4, 5-dihydro$2 \mathrm{H}$-pyran (Figure 1), and it fulfilled the molecular formula $\mathrm{C}_{13} \mathrm{H}_{14} \mathrm{O}_{7}$ with seven degrees of hydrogen deficiency.

Compound 2 obtained as white amorphous solid was determined to have the molecular formula $\mathrm{C}_{12} \mathrm{H}_{12} \mathrm{O}_{4}$ by a combination of HRESIMS, ${ }^{13} \mathrm{C}$, and $2 \mathrm{D}$ NMR data and indicated seven degrees of unsaturation. Its IR spectrum showed absorption bands at 3428, 3050, 1642, and 
TABLE 3: Bioactivities of tested compounds 1-5.

\begin{tabular}{|c|c|c|c|c|c|c|}
\hline \multirow{2}{*}{ Compounds } & \multicolumn{4}{|c|}{$\operatorname{MIC}\left(\mu \mathrm{g} \cdot \mathrm{mL}^{-1}\right)^{*}$} & \multicolumn{2}{|c|}{ Cytotoxicity** $^{* *}$} \\
\hline & S. aureus & B. licheniformis & E. xiangfangensis & E. fergusonii & P. aeruginosa & HTB-176, IC $_{50}$ \\
\hline 1 & $>25$ & $>25$ & $9.3 \pm 10.2$ & $>25$ & $7.4 \pm 2.4$ & Inactive \\
\hline 2 & $>25$ & $>25$ & $>25$ & $6.3 \pm 7.8$ & $5.7 \pm 5.9$ & $22 \pm 2.94$ \\
\hline 3 & $1.4 \pm 2.4$ & $>25$ & $>25$ & $2.5 \pm 1.7$ & $0.13 \pm 0.4$ & $10 \pm 3.92$ \\
\hline 4 & $>25$ & $>25$ & $>25$ & $>25$ & $12.5 \pm 14.2$ & $2 \pm 7.6$ \\
\hline 5 & $>25$ & $>25$ & $>25$ & $>25$ & $>25$ & Inactive \\
\hline Amikacin & 0.523 & 0.523 & 0.523 & 0.523 & 0.523 & - \\
\hline Kahalalide F & - & - & - & - & - & $4.3 \pm 0.25$ \\
\hline
\end{tabular}

${ }^{*} \mathrm{MIC}>25 \mu \mathrm{g} \cdot \mathrm{mL}^{-1} ;{ }^{* *} \mathrm{IC}_{50}$ in $\mu \mathrm{M}$.

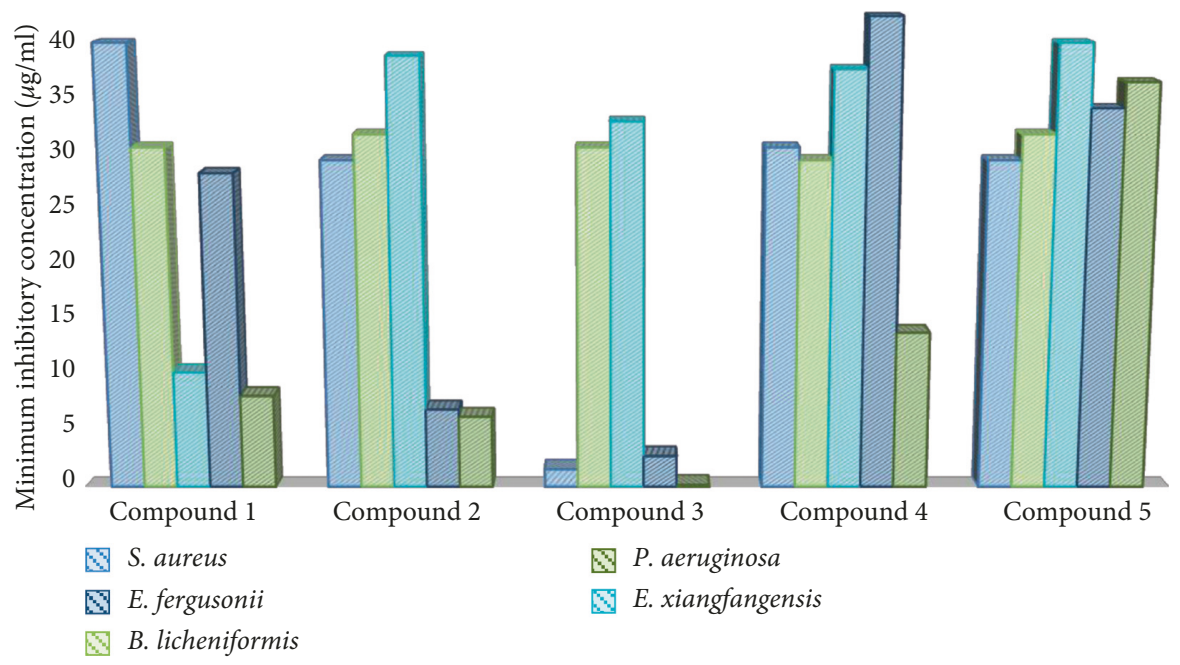

Figure 2: Average MIC values of the five tested compounds against all the test bacteria.

$1605 \mathrm{~cm}^{-1}$. The proton and carbon NMR data (Table 2) suggested the presence of a chelated hydroxyl group $\left[\delta_{\mathrm{H}} 11.1\right.$ $(\mathrm{s})]$, two meta-coupled aromatic protons $\left[\delta_{\mathrm{H}} 6.91(\mathrm{~d}\right.$, $\left.J=2.0 \mathrm{~Hz}), 6.83(\mathrm{~d}, J=2.0 \mathrm{~Hz}) ; \delta_{\mathrm{C}} 103.3,104.0\right]$, a secondary methyl group $\left[\delta_{\mathrm{H}} 1.35(\mathrm{~d}, J=7.0 \mathrm{~Hz}) ; \delta_{\mathrm{C}} 21.0\right]$, one methylene group $\left[\delta_{\mathrm{H}} 2.22(\mathrm{~d}, J=19.0 \mathrm{~Hz}) 2.93(\mathrm{dd}, J=19.0\right.$, $\left.6.5 \mathrm{~Hz}) ; \delta_{\mathrm{C}} 42.8\right]$, one methine group $\left[\delta_{\mathrm{H}} 3.52(\mathrm{dd}, J=6.5\right.$, $\left.7.0 \mathrm{~Hz}) ; \delta_{\mathrm{C}} 28.3\right]$, one methoxy group $\left[\delta_{\mathrm{H}} 3.95(\mathrm{~s}) ; \delta_{\mathrm{C}} 56.8\right]$, and a carbonyl carbon $\left(\delta_{\mathrm{C}} 196.2\right)$. The $\mathrm{CH}_{3}$ proton $\left(\delta_{\mathrm{H}} 1.35\right)$ showed strong ${ }^{3} J$ HMBC correlations with C-4a $\left(\delta_{\mathrm{C}} 145.1\right)$ and C-2 $\left(\delta_{\mathrm{C}} 42.8\right)$ and ${ }^{2} J$ correlations with C-3 $\left(\delta_{\mathrm{C}} 28.3\right)$. The proton and carbon NMR data with the help of HSQC and HMBC correlations confirmed that 2 contained a 1 -indanone skeleton [27] along with methyl, hydroxy, and methyl ester moieties attached to C-3, C-7, and C-5, respectively. Comparison of the NMR data of 2 with synthesized compound 5, 7-dimethoxy-3-methyl-1-indanone [28] revealed that the structures of both compounds are nearly identical, except for the presence of an ester group and hydroxyl moiety in 2 instead of two-methoxy group in the known synthesized compound. The location of the methyl ester moiety at position 5 was established by HMBC correlations of aromatic protons $\left(\delta_{\mathrm{H}} 6.91,6.83\right)$ with C-9 $\left(\delta_{\mathrm{C}} 166.9\right)$. In addition, the HMBC correlation of methoxy group $\left(\delta_{\mathrm{H}} 3.95\right)$ to carbonyl carbon $\left(\delta_{\mathrm{C}} 166.9\right)$ suggested the formation of a methyl methanoate moiety. The aromatic proton at $\delta_{\mathrm{H}} 6.91$ showed strong ${ }^{3} J$ correlations with C-3 $\left(\delta_{\mathrm{C}} 28.3\right), \mathrm{C}-6\left(\delta_{\mathrm{C}}\right.$ $104.0)$, and $C-7 \mathrm{a}\left(\delta_{\mathrm{C}} 148.0\right)$, and $\mathrm{C}-9\left(\delta_{\mathrm{C}} 166.9\right)$ suggested its position at $\mathrm{C}-4$ which further confirmed the presence of hydroxyl group at C-7 $\left(\delta_{\mathrm{C}} 164.2\right)$ not at C-4. The same chemical shifts and coupling constant values of $\mathrm{CH}_{2}-2$ and $\mathrm{CH}-3$ of 2 with previously synthesized compound (5methoxy-3-methyl-2, 3-dihydro-1H-inden-1-one) [29] were suggested alpha position of $8-\mathrm{CH}_{3}$ group at $\mathrm{C}-3$. On the basis of these evidences, the structure of compound 2 was established as 3 $\alpha$-methyl-7-hydroxy-5-carboxylic acid methyl ester-1-indanone. To our knowledge and current search of databases, the NMR data of compound 2 has not been described previously in the literature. It is worthy to mention that this is the third report of the isolation of indanone derivative from nature. It was described previously only from the marine fungus Phomopsis sp. [30] and the endophytic one Asperigullis flavipes [31].

All isolated compounds 1-5 were assayed for their antimicrobial activities against five pathogenic Gram-positive and Gram-negative bacterial strains Staphylococcus aureus, Bacillus licheniformis, Enterobacter xiangfangensis, Escherichia fergusonii, and Pseudomonas aeruginosa. The results were analyzed using the analysis of variance (ANOVA); the single-factor statistical tool indicated that there was a significant difference in the sensitivity of the tested microorganisms to the isolated compounds. The MICs ranged from 


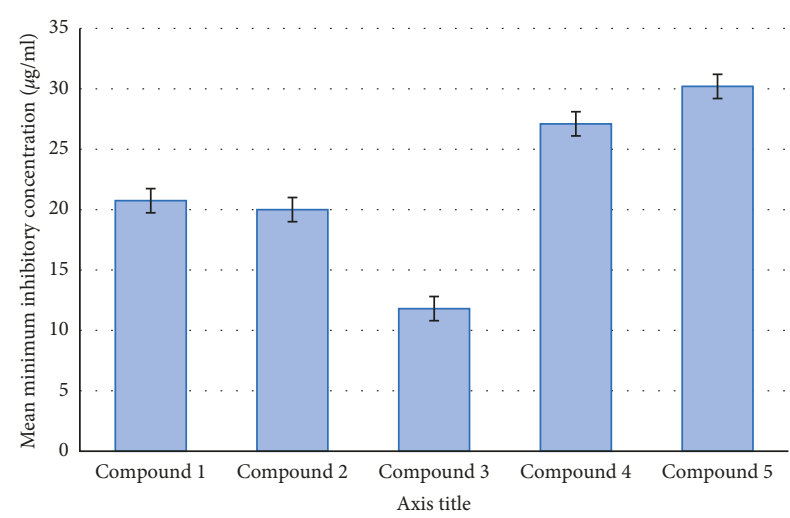

FIgUre 3: The mean MIC in $\mu \mathrm{g} \cdot \mathrm{mL}^{-1}$ of the five tested compounds against all the test bacteria.

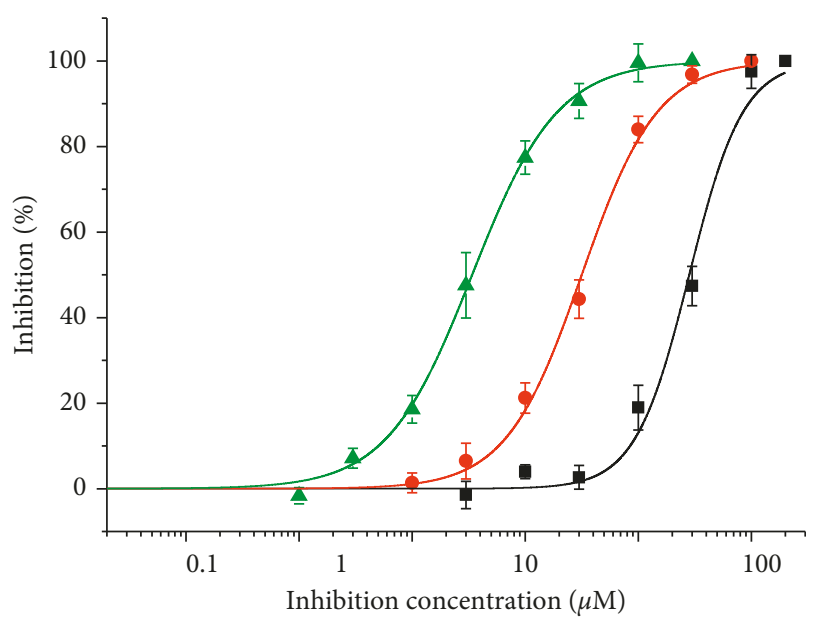

Figure 4: The dose-effect curve of the five tested compounds against HTB-176 human lymphoma cells.

$0.13 \pm 0.4$ to $12.5 \pm 14.2 \mu \mathrm{g} \cdot \mathrm{mL}^{-1}$ (Table 3 and Figure 2). Compound 3 is by far the most active component exhibiting MIC of $0.13 \pm 0.4,1.4 \pm 2.4$, and $2.5 \pm 1.7 \mu \mathrm{g} \cdot \mathrm{mL}^{-1}$ against $P$. aeruginosa, $S$. aureus, and E. fergusonii, respectively. These results are in agreement with earlier findings on the same compound derived from a Mangrove fungus [32].

Compounds 1 and 2 showed potent activity against the G-ve bacteria $P$. aeruginosa and E. fergusonii by MIC of $5.7 \pm 5.9$ and $6.3 \pm 7.8 \mu \mathrm{g} \cdot \mathrm{mL}^{-1}$ for compound 2 , respectively, and $7.4 \pm 2.4$ and $9.3 \pm 10.2 \mu \mathrm{g} \cdot \mathrm{mL}^{-1}$ for compound $\mathbf{1}$, respectively. Emodin, compound 4, inhibits the growth of only $P$. aeruginosa by $\mathrm{MIC}$ of $12.5 \pm 14.2 \mu \mathrm{g} \cdot \mathrm{mL}^{-1}$.

The mean difference between the MIC values of the isolated compounds against all tested pathogens was statistically significant $(P<0.05)$. The mean MIC of compound $5\left(29.85 \pm 31.07 \mu \mathrm{g} \cdot \mathrm{mL}^{-1}\right)$ was significantly higher than that of compound $3\left(9.30 \pm 11.08 \mu \mathrm{g} \cdot \mathrm{mL}^{-1}\right)$. Compound 5 was the least active extract and compound 3 the most potent extract (Figure 3).

In addition, compounds 1-5 were evaluated for their cytotoxicity toward HTB-176 human lymphoma cells using MTT assay. Compound $\mathbf{4}$ displayed the most potent cytotoxicity against the tested cell line, with an $\mathrm{IC}_{50}$ of $2 \pm 7.6 \mu \mathrm{M}$, followed by compound 3 with an $\mathrm{IC}_{50}$ of $10 \pm 3.92 \mu \mathrm{M}$ and compound 2 with an $\mathrm{IC}_{50}$ of $22 \pm 2.94 \mu \mathrm{M}$ (Figure 4). Compounds 1 and 5 were inactive in this bioassay (Table 3).

\section{Conclusions}

In conclusion, two new compounds were isolated from the thermophilic fungus Penicillium sp. RO-11. One of them is indanone derivative $\mathbf{2}$ which is unusual naturally occurring metabolite. Further three known compounds have been isolated and evaluated for their antibacterial and cytotoxicity effects. Compound 3 demonstrated significant antibacterial activity against $P$. aeruginosa, while compounds $\mathbf{2}$ and $\mathbf{1}$ exhibited moderate activities against the same bacterial strain. Compound $\mathbf{4}$ possesses potent anticancer property against human lymphoma HTB-176 cell line. The results presented here suggest that thermophilic fungi from extremely hot sources are a rich source of unique components that could have implication for development of drug candidates in the future.

\section{Data Availability}

The data used to support this study are available from the corresponding author.

\section{Conflicts of Interest}

The authors declare no conflicts of interest.

\section{Authors' Contributions}

R. O. conceived, designed, and performed the experiments; S. P. analyzed the data and wrote the paper.

\section{Acknowledgments}

This research project was supported by a grant from the "Research Center of the Female Scientific and Medical Colleges", Deanship of Scientific Research, King Saud University.

\section{Supplementary Materials}

Figure S1. 1H NMR spectra of compound 1. Figure S2. 13C NMR spectra of compound 1. Figure S3. DEPT-135 NMR spectra of compound 1. Figure S4. HMBC spectra of compound 1. Figure S5. HSQC spectra of compound 1. Figure S6. ESI mass spectra of compound 1. Figure S7. ESI mass spectra of compound 1. Figure S8. ESI mass spectra of compound 1. Figure S9. 1H NMR spectra of compound 2. Figure S10. 13C NMR spectra of compound 2. Figure S11. DEPT-135 NMR spectra of compound 2. Figure S12. HMBC spectra of compound 2. Figure S13. HSQC spectra of compound 2. Figure S14. ESI mass spectra of compound 2. (Supplementary Materials) 


\section{References}

[1] M. M. S. Moretti, D. A. Bocchini-Martins, R. D. Silva, A. Rodrigues, L. D. Sette, and E. Gomes, "Selection of thermophilic and thermotolerant fungi for the production of cellulases and xylanases under solid-state fermentation," Brazilian Journal of Microbiology, vol. 43, no. 3, pp. 10621071, 2012.

[2] R. Maheshwari, G. Bharadwaj, and M. K. Bhat, "Thermophilic fungi: their physiology and enzymes," Microbiology and Molecular Biology Reviews, vol. 64, no. 3, pp. 461-488, 2000.

[3] D. S. Allison, M. W. Rey, R. M. Berka, G. Armstrong, and N. S. Dunn-Coleman, "Transformation of the thermophilic fungus Humicola grisea var. thermoidea and overproduction of Humicola glucoamylase," Current Genetics, vol. 21, no. 3, pp. 225-229, 1992.

[4] J. Mouchacca, "Thermophilic fungi: biodiversity and taxonomic status," Cryptogamy Mycology, vol. 18, pp. 19-69, 1997.

[5] R. Redman, A. Litvintseva, K. Sheehan, J. Henson, and R. Rodriguez, "Fungi from geothermal soils in yellowstone national park," Applied and Environmental Microbiology, vol. 65, pp. 5193-5197, 1999.

[6] Y.-L. Yang, C.-P. Lu, M.-Y. Chen, K.-Y. Chen, Y.-C. Wu, and S.-H. Wu, "Cytotoxic polyketides containing tetramic acid moieties isolated from the fungus Myceliophthora thermophila: elucidation of the relationship between cytotoxicity and stereoconfiguration," Chemistry -A European Journal, vol. 13, no. 24, pp. 6985-6991, 2007.

[7] Y.-L. Yang, W.-Y. Liao, W.-Y. Liu et al., "Discovery of new natural products by intact-cell mass spectrometry and LCSPE-NMR: malbranpyrroles, novel polyketides from thermophilic fungus malbranchea sulfurea," Chemistry-A European Journal, vol. 15, no. 43, pp. 11573-11580, 2009.

[8] Y.-S. Chu, X.-M. Niu, Y.-L. Wang et al., "Isolation of putative biosynthetic intermediates of prenylated indole alkaloids from a thermophilic fungus Talaromyces thermophilus," Organic Letters, vol. 12, no. 19, pp. 4356-4359, 2010.

[9] J.-P. Guo, J.-L. Tan, Y.-L. Wang et al., "Isolation of talathermophilins from the thermophilic fungus Talaromyces thermophilus YM3-4," Journal of Natural Products, vol. 74, no. 10, pp. 2278-2281, 2011.

[10] J.-P. Guo, C.-Y. Zhu, C.-P. Zhang et al., "Thermolides, potent nematocidal PKS-NRPS hybrid metabolites from thermophilic fungus Talaromyces thermophilus," Journal of the American Chemical Society, vol. 134, no. 50, pp. 20306-20309, 2012.

[11] P. Kirk, P. Cannon, D. Minter, and J. Stalpers, Dictionary of the Fungi, CABI, Wallingford, UK, 10th edition, 2008.

[12] G. Strobel and B. Daisy, "Bioprospecting for microbial endophytes and their natural products," Microbiology and Molecular Biology Reviews, vol. 67, no. 4, pp. 491-502, 2003.

[13] A. Kozlovsky, V. Zhelifonova, and T. Antipova, "Biologically active metabolites of Penicillium fungi," Journal of Organic \& Biomolecular Chemistry.vol. 1, pp. 11-21, 2013.

[14] Y. Liu, T. Kurtán, C. Yun Wang et al., "Cladosporinone, a new viriditoxin derivative from the hypersaline lake derived fungus Cladosporium cladosporioides," The Journal of Antibiotics, vol. 69, no. 9, pp. 702-706, 2016.

[15] R. S. Orfali, A. H. Aly, W. Ebrahim et al., "Pretrichodermamide $\mathrm{C}$ and $\mathrm{N}$-methylpretrichodermamide $\mathrm{B}$, two new cytotoxic epidithiodiketopiperazines from hyper saline lake derived Penicillium sp," Phytochemistry Letters, vol. 11, pp. 168-172, 2015.

[16] R. S. Orfali, A. H. Aly, W. Ebrahim, R. Rudiyansyah, and P. Proksch, "Isochroman and isocoumarin derivatives from hypersaline lake sediment-derived fungus Penicillium sp.," Phytochemistry Letters, vol. 13, pp. 234-238, 2015.

[17] H. Hayashi, M. Mukaihara, M. S. Murao, A. Y. Lee, and J. Clardy, "Acetoxydehydroaustin, a new bioactive compound, and related compound neoaustin from Penicillium sp. MG11," Bioscience, Biotechnology, and Biochemistry, vol. 58, no. 2, pp. 334-338, 1994.

[18] J. Wells, R. Cole, and J. Kirksey, "Emodin, a toxic metabolite of Aspergillus wentii isolated from weevil-damaged chestnuts," Applied and Environmental Microbiology, vol. 30, pp. 26-28, 1975.

[19] M. F. Elsebai, V. Rempel, G. Schnakenburg, S. Kehraus, C. E. Müller, and G. M. König, "Identification of a potent and selective cannabinoid CB1 receptor antagonist from auxarthron reticulatum," ACS Medicinal Chemistry Letters, vol. 2, no. 11, pp. 866-869, 2011.

[20] P. Singh, C. Raghukumar, R. M. Meena, P. Verma, and Y. Shouche, "Fungal diversity in deep-sea sediments revealed by culture-dependent and culture-independent approaches," Fungal Ecology, vol. 5, no. 5, pp. 543-553, 2012.

[21] J. Kjer, A. Debbab, A. H. Aly, and P. Proksch, "Methods for isolation of marine-derived endophytic fungi and their bioactive secondary products," Nature Protocols, vol. 5, no. 3, pp. 479-490, 2010.

[22] V. Berghe and A. Vlietinck, "Screening methods for antibacterial and antiviral agents from higher plants," Methods in Plant Biochemistry, vol. 6, pp. 47-68, 1991.

[23] M. Ashour, R. Edrada, R. Ebel et al., "Kahalalide derivatives from the Indian sacoglossan Mollusk elysiagrandifolia," Journal of Natural Products, vol. 69, no. 11, pp. 1547-1553, 2006.

[24] T. Shimoyama, M. Miyoshi, T. Nehira et al., "Two new secondary metabolites from a fungus of the genus Robillarda," The Journal of Antibiotics, vol. 71, no. 4, pp. 432-437, 2018.

[25] D. Rebollar-Ramos, M. L. Macías-Ruvalcaba, M. Figueroa, H. A. Raja, M. González-Andrade, and R. Mata, "Additional $\alpha$-glucosidase inhibitors from Malbranchea flavorosea (leotiomycetes, ascomycota)," The Journal of Antibiotics, vol. 71, no. 10 , pp. $862-871,2018$.

[26] M. F. Abdelwahab, M. A. Fouad, M. S. Kamel et al., "Tanzawaic acid derivatives from freshwater sediment-derived fungus Penicillium sp.," Fitoterapia, vol. 128, pp. 258-264, 2018.

[27] V. Buadam, Y. Sukpondma, S. Phongpaichit, J. Sakayaroj, and N. Hutadilok-Towatana, "Indanone and mellein derivatives from the Garcinia-derived fungus Xylaria sp. PSU-G12," Phytochemistry Letters, vol. 6, no. 1, pp. 135-138, 2013.

[28] E. Fillion and D. Fishlock, "Convenient access to polysubstituted 1-indanones by Sc(OTf)3-Catalyzed intramolecular friedel-crafts acylation of benzyl meldrum's acid derivatives," Organic Letters, vol. 5, no. 24, pp. 4653-4656, 2003.

[29] E. J. Rastelli, N. T. Truong, and D. M. Coltart, "Asymmetric induction in hydroacylation by cooperative iminium iontransition-metal catalysis," Organic Letters, vol. 18, no. 21, pp. 5588-5591, 2016.

[30] C. Yiguang, P. Jiahui, X. Fang et al., "A new indene derivative from the marine fungus Phomopsis sp. (no. GX7-4A)," Chemistry of Natural Compounds, vol. 46, no. 2, pp. 230-232, 2010.

[31] A. Najeeb, P. Chengqian, L. Yanqin, S. Yutong, and W. Bin, "Isolation and structure determination of a new indene derivative from endophytic fungus Aspergillus flavipes Y-62," Natural Product Research, vol. 10, pp. 1-6, 2018.

[32] G.-L. Huang, X.-M. Zhou, M. Bai et al., "Dihydroisocoumarins from the mangrove-derived fungus Penicillium citrinum," Marine Drugs, vol. 14, no. 10, pp. 177-184, 2016. 

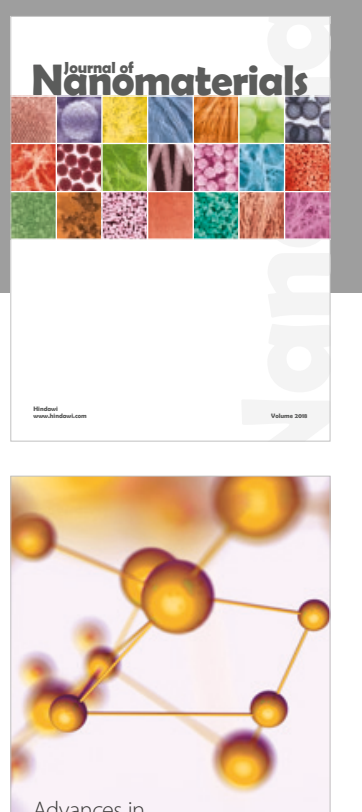

Physical Chemistry
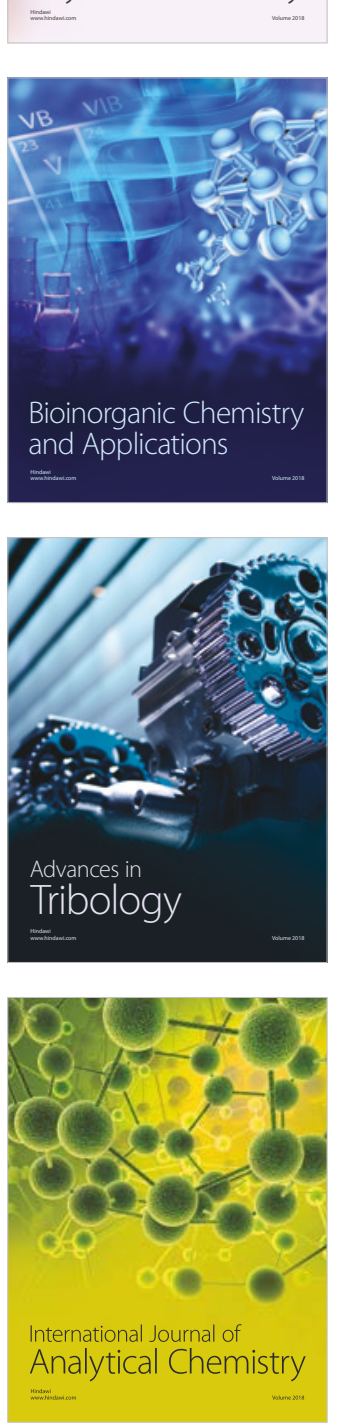

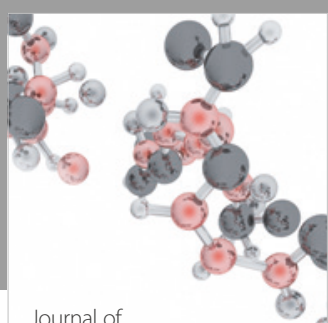

Analytical Methods

in Chemistry

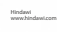

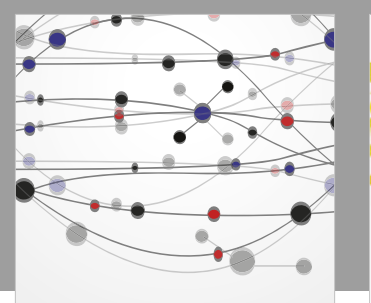

The Scientific World Journal

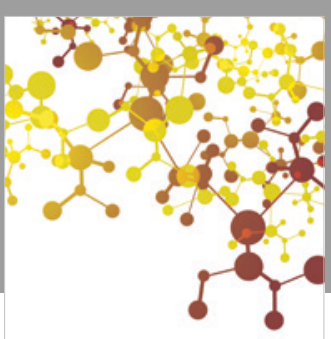

Journal of

Applied Chemistry
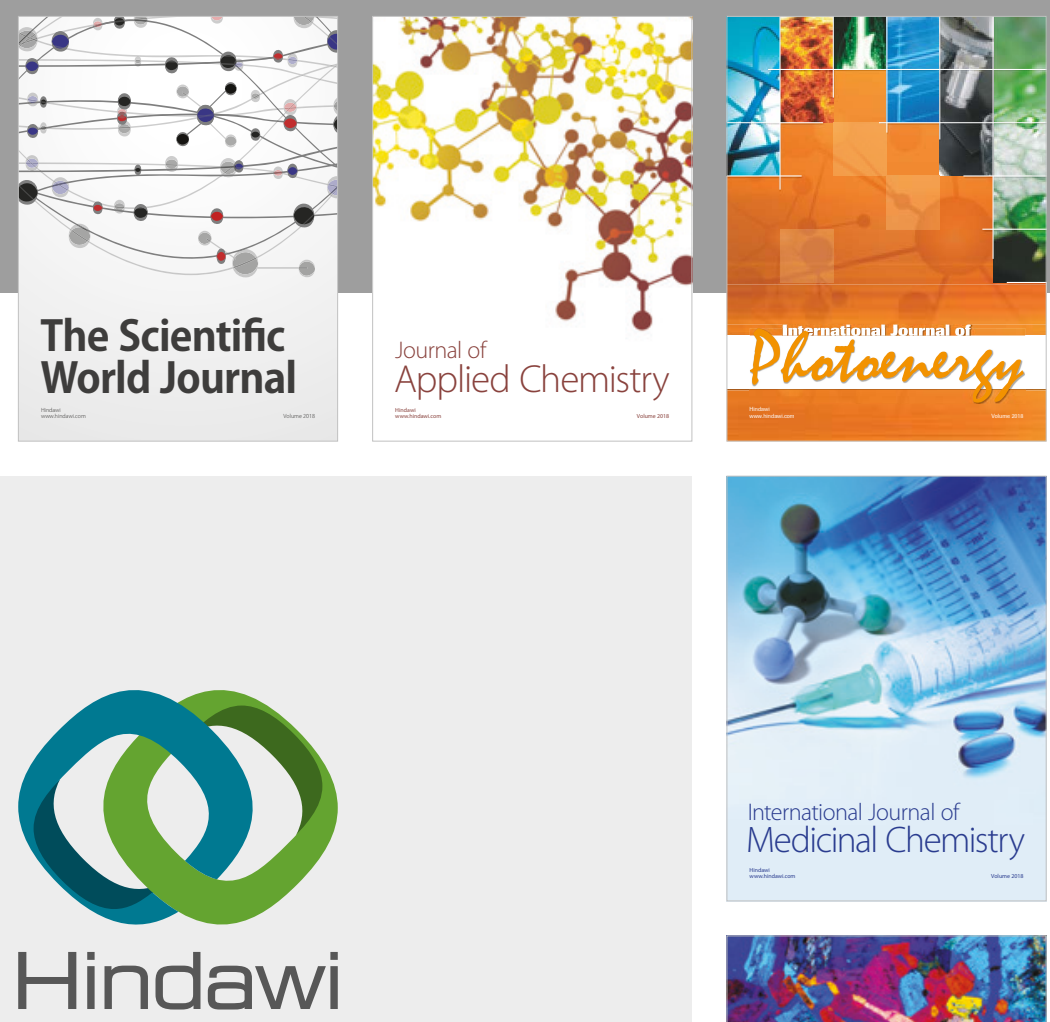

Submit your manuscripts at

www.hindawi.com
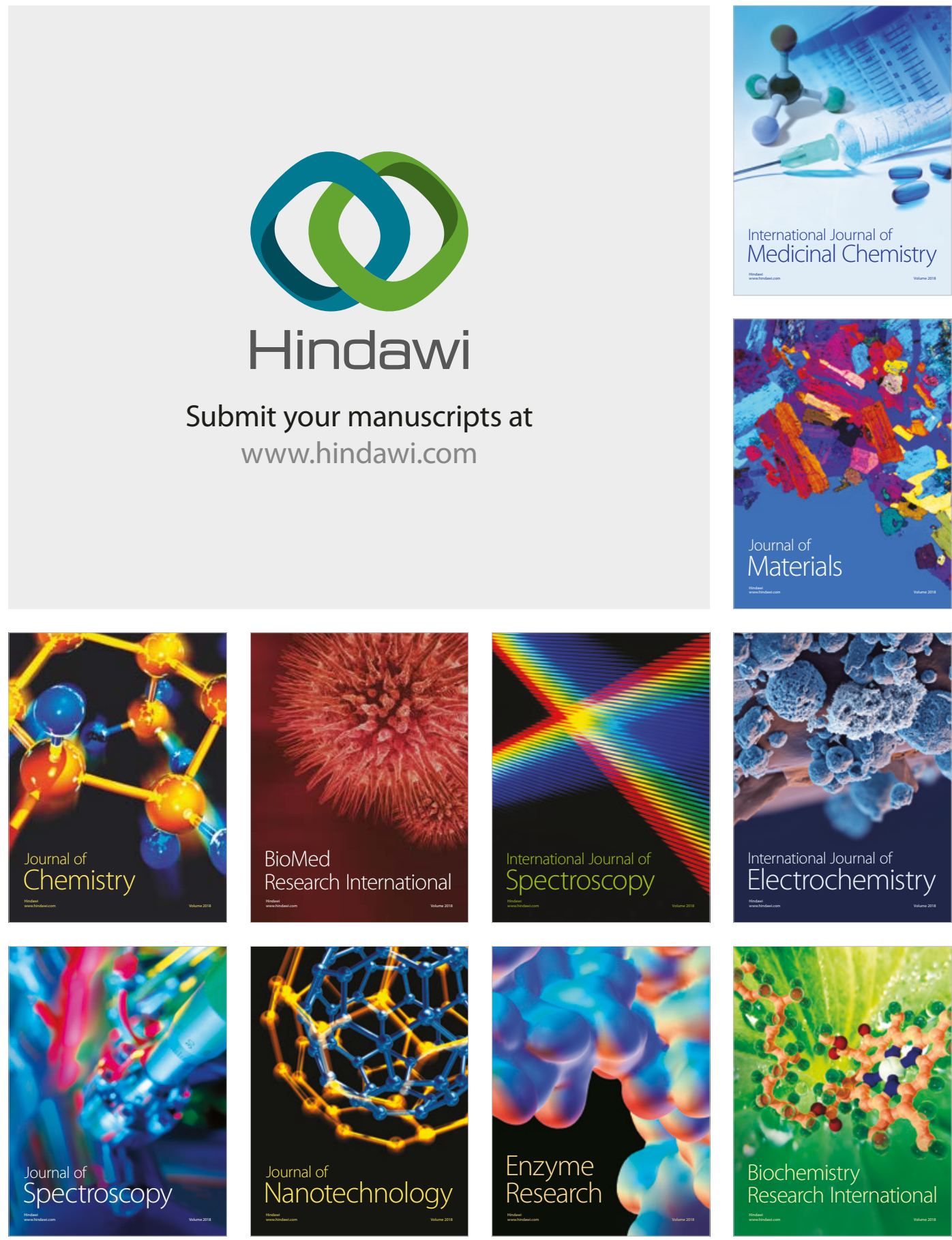
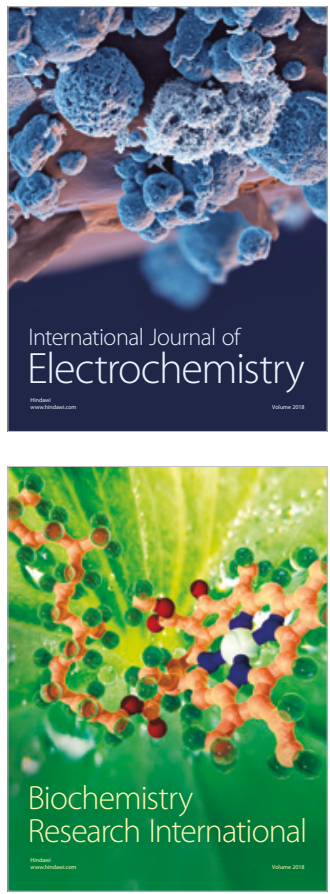